International Journal of Social Sciences and Humanities
Available online at www.sciencescholar.us
Vol. 5 No. 1, April 2020, pages: $32-44$
e-ISSN: 2550-7001, p-ISSN: 2550-701X
https://doi.org/10.29332/ijssh.v5n1.850

\title{
Articulation of Media on Juvenile Delinquency with Special Reference to India
}

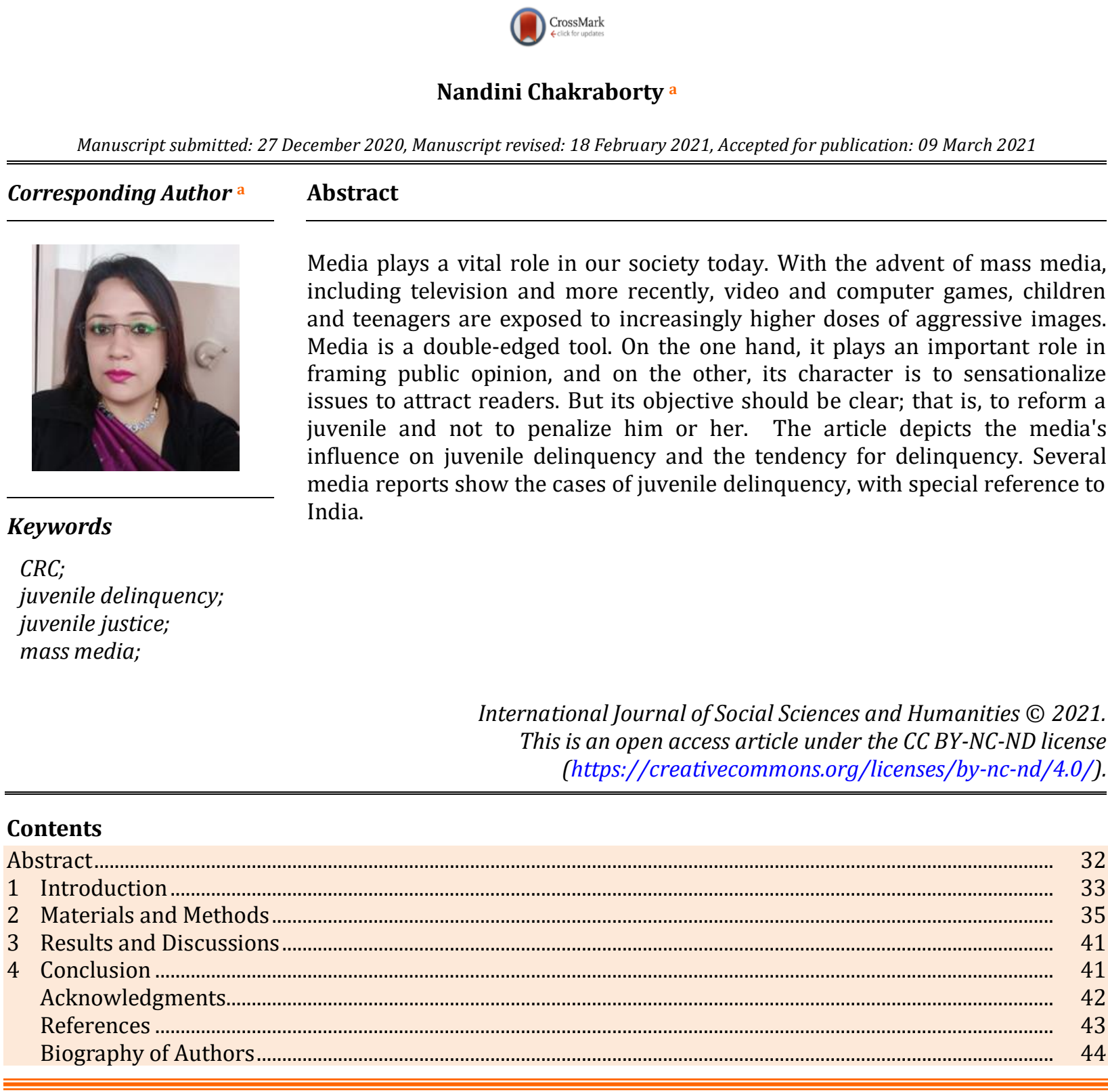

\footnotetext{
a Journalism and Mass Communication, Mrinalini Datta Mahavidyapith, Kolkata, West Bengal, India
} 


\section{Introduction}

Swami Vivekananda said (on child psychology), "each man in his childhood runs through the stages through which his race has come up; only the race took thousands of years to try to do it, while the child takes a few years. The child is first the old savage man - and he crushes a butterfly under his feet. The child is initially just like the primitive ancestors of his race. As he grows, he passes through different stages until he reaches the event of his race. Only he does it swiftly and quickly." He also said, "There is hardly a child, born in any country in the world, who has not been told, "Do not steal," "Do not tell a lie," but nobody tells the child how he can help to do them. Talking will not help him. Why should he not become a thief? We do not teach him how not to steal; we simply tell him, "Do not steal." Only when we teach him to control his mind do we help him."

In the article Media and Violence the author Joe Goebel said that in the first-ever conducted international survey on children and media violence (2012), a UNESCO study underlines television's dominant role in the lives of young people around the world and its impact on the development of aggressive behavior, paving the way for a stronger debate between politicians, producers, teachers, and parents. The media plays a major role in the development of cultural orientations, world views, and beliefs. Media can contribute a lot to society. It can change opinions because they need access to people and this provides it tons of strength. This strength can either be used constructively by educating the people or it is often used destructively by misleading innocent people, the foremost important use of media is to educate the people about essential human rights.

Media plays a big role in our society today. It is all around us, from the shows we watch on television, the music we hear on the radio, to the books and magazines we read every day. Media plays an important role in our society and maybe a part of our life. Media may be a bridge between the governing bodies and the general public. It is a strong and versatile tool that influences the general public to an excellent extent. Media is the voice of the voiceless and an excellent force in building the state. A "juvenile" or "child" means a person who has not completed his eighteenth year of age. A boy or girl under 18 years of age is a juvenile or child under section 2(k) of JJA 2000. The age of juvenility of a boy child under JJA 1986 was below 16 years and that of a girl child was below 18 years of age. Those working within the field of youngsters had campaigned to extend the age of boy juveniles to bring it on par with girl juveniles. The age of a boy juvenile has been increased to 18 years by Juvenile Justice Act 2000 mainly to bring juvenile legislation into conformity with the CRC which the Government of India had ratified on 11th December 1992. The Statement of Objects and Reasons of JJA 2000 has indicated this non-conformity as being a ground for amending JJA 1986 (Dietrich et al., 2001; Chabrol et al., 2009).

Article 1 of CRC (The Convention on the Rights of the Child) states that "For the needs of this Convention, a toddler means, "Every human being below the age of 18 years unless, under the law applicable to the child, the majority is attained earlier." So currently both boys and girls below 18 years aged enjoy the protection of juvenile legislation. Whatever be the reason for increasing the age of the boy juvenile, it was vital to do so and is welcomed. Juvenile delinquency (2005), or offending, are often separated into three categories: delinquency, crimes committed by minors which are addressed by the juvenile courts and justice system; criminal behavior, crimes dealt with by the criminal justice system, and standing offenses, offenses which are only classified intrinsically because one may be minor, like truancy, also addressed by the juvenile courts.

The study focuses-to find the Media influences on juvenile delinquency in India. To understand the effects of violence in audiovisual programming on a youth's tendency for juvenile delinquency and violence especially in India.

\section{Literature review}

According to the developmental research of Moffitt (2006), two different types of offenders emerge in adolescence. One is that the repeat offender mentioned because the life-course-persistent offender, who begins offending or showing aggressive behavior in adolescence (or even childhood) and continues into adulthood; and therefore the age-specific offender, mentioned because the adolescence-limited offender, for whom juvenile offending or delinquency begins and ends during their period of adolescence. Because most teenagers tend to show some form of antisocial, aggressive, or delinquent behavior during adolescence, it important to account for these behaviors in childhood, to determine whether they are going to be life-course-

Chakraborty, N. (2021). Articulation of media on juvenile delinquency with special reference to India. International Journal of Social Sciences and Humanities, 5(1), 32-44. https://doi.org/10.29332/ijssh.v5n1.850 
persistent offenders or adolescents-limited offenders. Although adolescent-limited offenders tend to drop all criminal activity once they enter adulthood, and show less pathology than life-course-persistent offenders, they still show more psychological state, drug abuse, and financial problems, both in adolescence and adulthood, than those that were never delinquent (Mulvey et al., 1993; Ryan et al., 2008).

Of the published works, eight studies by Hansa Sheth (1961), B.K. Bhattacharya (1962), A.D. Attar (1964), Sushil Chandra (1967), S.C. Verma (1969), and Harjeet S. Sandhu (1977) and three studies by the Government of India (1952, 1954, and 1970) are considered to be more significant. Based on these studies and based on data compiled by the National Crime Records Bureau, 1998, the following characteristics of juvenile delinquency in India may be given: The delinquency rates are repeatedly higher for boys than girls, that is, girls commit fewer delinquencies than boys. The percentage involvement of women in delinquency up to 1987 was about 6-7 percent. This suddenly increased to 13.4 percent in 1988 thanks to a change within the definition of juveniles, by which girls within the age bracket of 7-18 years only were considered as juveniles.

Questions about the effects of media violence have been around since the beginning of television. The first mention of a priority about television's effects upon our youngsters is often found in many Congressional hearings as early because the 1950s. For example, the US Senate Committee on delinquency held a series of hearings during 1954-55 on the impact of television programs on juvenile crime. These hearings were only the beginning of continuing congressional investigations by this committee and others from the 1950s to the present. In addition to the congressional hearings begun in the 1950s, many reports have been written by the National Commission on the Causes and Prevention of Violence, surgeon General's Scientific Advisory Committee on Television and Social Behavior (1972); the report on children and television drama by the Group for the Advancement of Psychiatry (1982), Mental Health, Television, and Behavior Report (Pearl, Bouthilet, \& Lazar, 1982); National Research Council (1993), violence report; and reports from the American Psychological Association's "Task Force on Television and Society" (Huston et al., 1992) and "Commission on Violence and Youth" (American Psychological Association, 1992; Donnerstein.

From 1996 to 1997, more than 5,000 12-year-old students from 23 countries (Angola, Argentina, Armenia, Brazil, Canada, Costa Rica, Croatia, Egypt, Fiji, Germany, India, Japan, Mauritius, the Netherlands, Peru, Philippines, Qatar, South Africa, Spain, Tajikistan, Togo, Trinidad and Tobago, Ukraine) answered a standardized 60-item questionnaire. Regional pre-tests assured that the youngsters understood the questionnaire, which they filled in during classes. Out of school children or groups living in extremely remote areas could not be covered. The study aimed to understand the role of the media in the lives of children; children's fascination for media violence; the relationship between media violence and aggressive behavior among children; the cultural and gender differences in the media impact on aggression; and how violent environments (war/crime) and the level of technological development influence the coping with aggressive media content. The study was conducted under Dr Jo Groebel of Utrecht University, with the World Organization of the Scout Movement accepting overall responsibility for the fieldwork through their international network.

In 'Children, violence, and the media' (A Report for Parents and Policy Makers) Senate Committee on the Judiciary Senator Orrin G. Hatch, Utah, Chairman Committee on the Judiciary Prepared by Majority Staff Senate Committee on the Judiciary September 14, 1999, observed that Americans have grown increasingly alarmed about youth violence. This report identifies and begins to redress one among the principal causes of youth violence: media violence. According to the United States Department of Justice ("DOJ"), law enforcement agencies arrested approximately 2.8 million juveniles in 1997. Of that number, 2,500 were arrested for murder and 121,000 for other violent crimes. Juveniles accounted for $19 \%$ of all arrests, $14 \%$ of murder arrests, and $17 \%$ of all violent crime arrests. According to DOJ, the amount of juvenile violent crime arrests in 1997 exceeded the 1988 level by 49\% (Chopra, 2015; Desai, 1979; Kumari, 2011).

A study conducted in 1989, on video game usage and content found that most of the arcade games contained "antisocial values of a violent nature" (Ivory, 2001). In the article, 'Media Access to Juvenile Proceedings: balancing the tightrope between privacy rights and freedom of the press' (on March 2015 in, international journal of law crime and justice 43(4)), authors Claire Nolasco, Aneta Spaic, Michael S. Vaughn wrote, that, the first amendment to the U.S. Constitution has been invoked as the basis for the grant of media access to adult trials. Because the U.S. Supreme Court has not determined that the first amendment right of public access similarly applies to juvenile delinquency proceedings, juvenile courts are faced with the issue of balancing the juvenile's privacy rights with the media's right to access information. This article researches 
media access to juvenile delinquency proceedings, including, the standards, limits, and conditions for such access through analyzing decisions of United States federal and state courts.

\section{Materials and Methods}

This is the story of a boy who brutally stabbed his father, stepmother, and his stepbrother and celebrated the victory and execution of his plans by eating sweets or two sixteen-year-old boys in Kolkata who raped their friend sister and then casually left for playing football or the MMS scandal of two students in Delhi, all fall under the preview of juvenile crime. Juvenile crime has become a global emerging issue. Today juvenile crimes are increasing at an alarming rate. And so do in India it has become a major problem that demands immediate attention and control measures.

It's no doubt television provide us news update, entertainment movies, weather conditions, various competitive exams, etc. So it's a good approach by media to provide homemade services in a short interval of time. But some channels for their popularity and money start porn serials, movies, and many more. Children begin watching television at a very early age, sometimes as early as six months, and are intense viewers by the time that they are two or three years old. In most cases, the amount of televised viewing becomes greater with age and then tapers off during adolescence. The violence that is viewed is more important than the amount of television that is viewed. With the advent of mass media, including television and more recently, video and computer games, children and teenagers are exposed to increasingly higher doses of aggressive images. In many countries, there is an average of five to ten aggressive acts per hour of television. Violence among youth is also on the rise, making it plausible to correlate the two, even though we believe that the primary causes for aggressive behavior in children are to be found how in their family environment, and the social and economic conditions in which they are raised.

Media plays a major role in the development of cultural orientations, world views, and beliefs. Most studies show that the relation between media violence and real violence is interactive; media can contribute to an aggressive culture; people who are already aggressive use the media as further confirmation of their beliefs and attitudes, which, in turn, are reinforced through media content. As the basis for this study, we formulated the compass theory. Depending on a child's already existing experiences, values, and cultural environment, media content offers an orientation, a frame of reference which determines the direction of one's behavior. Viewers do not necessarily adapt what they have observed, but they measure their behavior in terms of distance to the perceived media models.

Media is a double-edged tool. On the one hand, it plays an important role in framing public opinion, and on the other, its character is to sensationalize issues to attract readers. In furtherance of its objective to reform a juvenile and not penalize him, section 19 has been incorporated in JJA 2000. This section ensures that "a juvenile who has committed an offense and has been dealt with under the provisions of this Act shall not suffer disqualification, if any, attaching to a conviction of an offense under such law." An identical provision was contained in JJA 1986.

Furthermore, subsection (2) of section19 states, "The Board shall make an order directing that the relevant records of such conviction shall be removed after the expiry of the period of appeal or a reasonable period as prescribed under the rules, as the case may be." The Model Rules provide for the records or documents relating to a juvenile to be preserved for 7 years, and thereafter to be destroyed by the Board. The law, thus, sends a clear message that the future of a child is not to be adversely impacted due to his past conduct. Despite the inclusion of section 19 in the statute, juveniles in conflict with the law find it difficult to re-join mainstream society. Schools have been known to expel juveniles in conflict with law claiming that they would be a bad influence upon the other students. Their employment opportunities dwindle as the stigma follows them into the job market, and they are compelled to depend upon the underpaid unorganized sector for earning a livelihood. To reduce this victimization, juvenile legislation protects the juvenile's right to privacy by restricting media reportage.

In the article, 'Media and juvenile delinquency: A study into the relationship between journalists, politics, and public', authors, Nel Ruigrok, Wouter van Atteveldt, Sarah Gagestein, (First Published March 16, 2016 ), stated that, Between 2007 and 2011, the number of registered juvenile suspects declined by 44 percent, but the Dutch public did not feel any safer. The research states that, media coverage of youth crime and

Chakraborty, N. (2021). Articulation of media on juvenile delinquency with special reference to India. International Journal of Social Sciences and Humanities, 5(1), 32-44. https://doi.org/10.29332/ijssh.v5n1.850 
interviews journalists and their sources in order to investigate the relationship between journalists, their sources, and the possible effects on the public with respect to fear of crime. They find an over representation of youth crime in news coverage, especially in the popular press, and a stronger episodic focus over time. All media focus increasingly on powerful sources that focus on repressive framing, but this is especially found in the elite press. They conclude that news coverage in all media groups, although in different ways, does contribute to the fear of crime in society and the idea that repressive measures are needed. The fact that this fear of crime is also caused by news coverage is acknowledged, but neither journalists nor politicians are able or willing to change this.

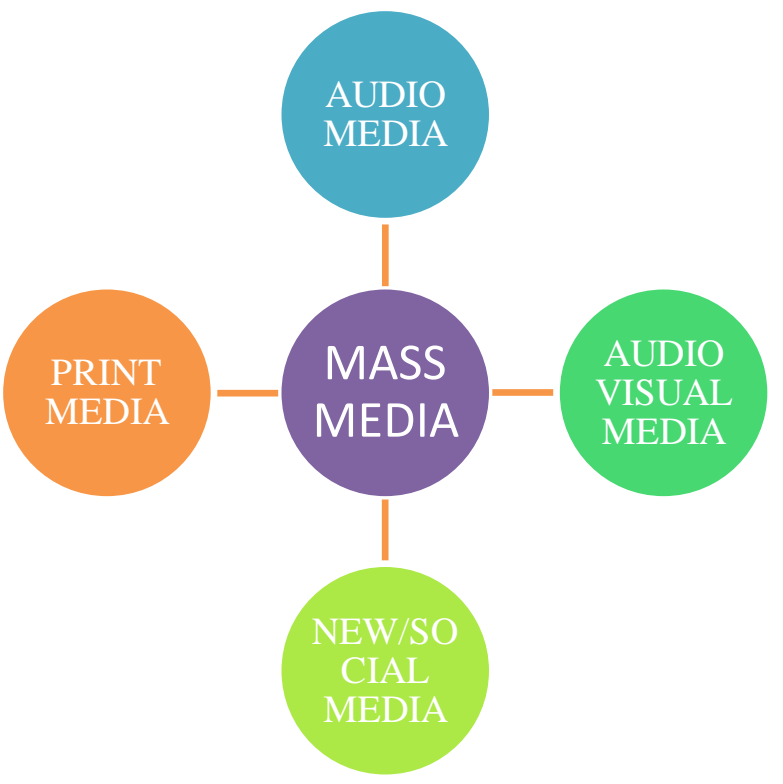

Figure 1. Mass Media

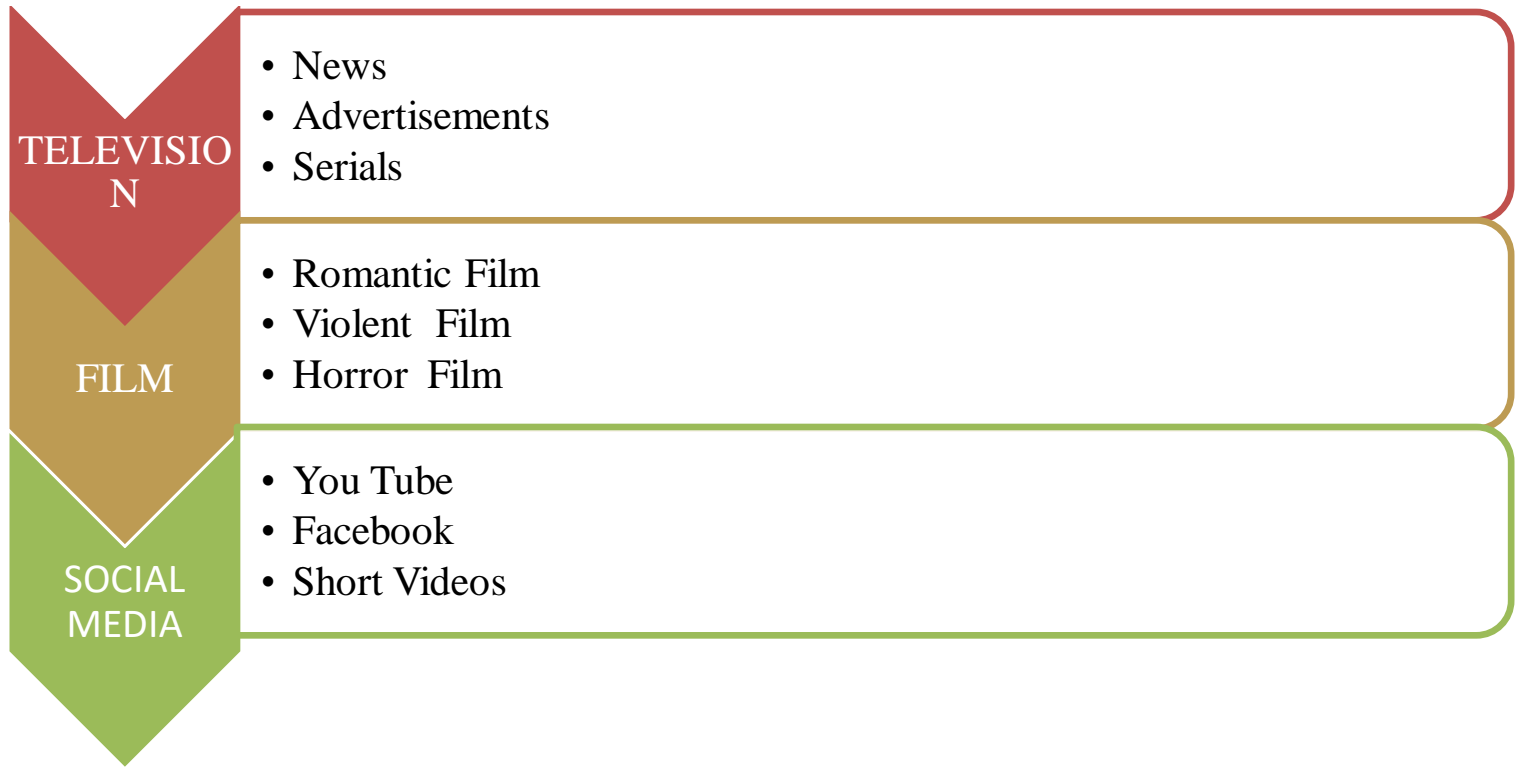

Figure 2. Types of Audio Visual Media 
Stories involving young people are most commonly about crime; gangs; education; and social exclusion

Young offenders are likely to receive negative coverage

The media often reports stories in a sensational

way

The media does not always represent reality

Most young people feel the media represents them as antisocial and a group to be feared

Figure 3. Factors Affecting Youth by Media

Various Types of T.V Programmes Lead Children towards Juvenile Delinquency:

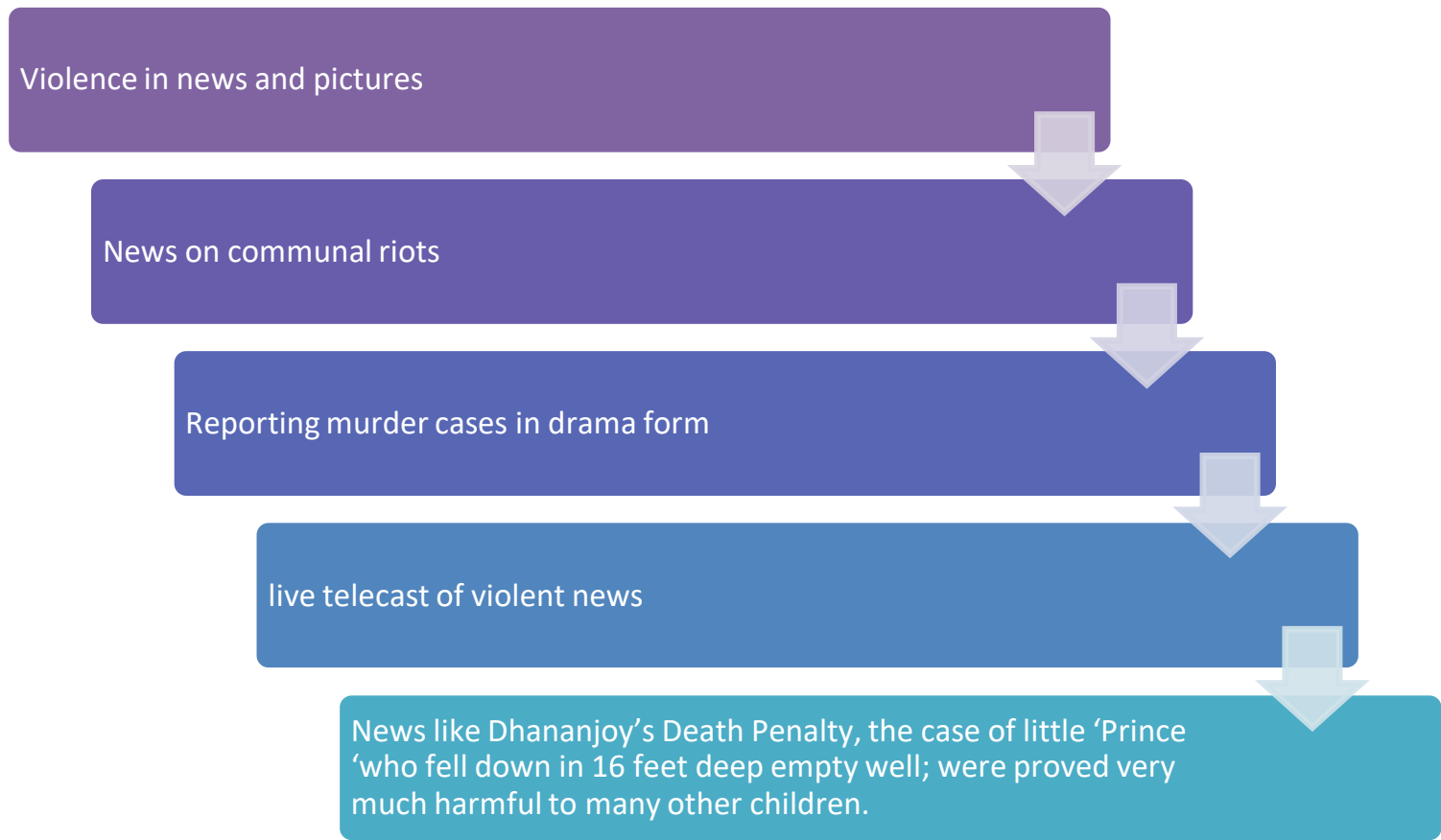

Figure 4. Television News

Chakraborty, N. (2021). Articulation of media on juvenile delinquency with special reference to India. International Journal of Social Sciences and Humanities, 5(1), 32-44. https://doi.org/10.29332/ijssh.v5n1.850 


\section{Thumps up, Pepsi,Coke; with their adventurous and} deadly advertisements

Prohibited advertisements on private channels and also in news channels

Promotional advertisements of many adult films

Figure 5. T.V advertisements

Ramayana, Mahabharata, Shaktiman, and many other historical serials introduce judha- judha game among children

Balika badhu, Bind banunga ghori charunga, Phoolba ,Sasural simor ka introduce bin-bindni(childhood marriage) concept

Crime Petrol, Adalat, Ankho Dekhi ,CID,Sabdhan India; these kind

of serials influenced the children to crime

Slang languages are always used in lifestyle reality shows like big boss, Roadies, M. TV Bakhra, Survivor India etc.

Figure 6. TV serials 
Cartoon series like Tom and Jerry, Sinchan, Oggi and

Cockroaches, Poppay show, Nobbita and many other popular

cartoons show how to irritate and tackle others.

Different websites, you tube channels

Different video games, violent animated games.

Figure 7. Cartoons

$>$ Today joint family's does not exist and in nuclear family there is less supervision on

child.

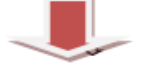

The parents are usually working.

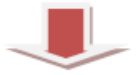

Thus ignorance, spending less quality time with child,

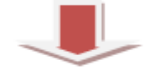

Laxity in parental control over children

-

Rapidly changing patterns in modern living

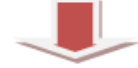

Bad and influential peer group

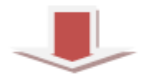

Sometimes violence or stressful atmosphere of home leads to a vacuum in the minds of

children.

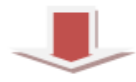

There is a feeling of helplessness and in affection that grows within them.

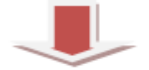

Thus to avoid such mood they retort to various kinds of TV. Programmers.

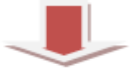

Special interest to see action movies and horror movies

Figure 8. Causes behind TV, Mobile and Computer affection from childhood

Chakraborty, N. (2021). Articulation of media on juvenile delinquency with special reference to India. International Journal of Social Sciences and Humanities, 5(1), 32-44. https://doi.org/10.29332/ijssh.v5n1.850 
Childhood period is a risky period. It is a very delicate period that decides the remaining future of the child, thus, any lack of supervision can distort the future of the child completely.

\section{Ban on Trial by Media imposed by Juvenile Justice}

Indian Media remembers Lippmann's quote that there can be no higher law in journalism than, to tell the truth and to shame the devil but forgets Section 21 of Juvenile Justice Act which is inspired by the UNCRCUnited Nations Convention on the Rights of the Child is a good law. It has a specific provision that bans trial by media. However, on $3^{\text {rd }}$ June, 2009, a news item appeared in the New Delhi Edition of The Times of India on page 4, titled "boy shoots friend over TV remote". It reveals the age, name, and address of the juvenile in question.

It's high time for the National Commission for Protection of Child Rights (NCPCR) to act as we attach immense importance to the rule of law and the right to fair trial, with special emphasis with regards to juveniles in conflict with the law. In fact, since $2^{\text {nd }}$ June, 2007, the media has been extensively covering and sensationalizing the case of a nine-year-old juvenile who has allegedly killed three children in the past year. The press has branded him as a 'serial killer'; it has gone to the extent of publishing his photograph with such news items along with the name of his village.

The press has grossly disregarded Section 21 of the Juvenile Justice Act, 2006 enacted by the Government of India which prohibits the publication of the name, address, or any other particulars calculated to lead to the identification of the juvenile. The said provision also prohibits the publication of the juvenile's picture. However, only if the inquiring authority in the interest of the juvenile permits such disclosure in writing, then the press is justified in publishing such news.

\section{Law of Cinematography}

It is reported that the student was influenced by the movie Agneepath which depicted a story of a young man who takes revenge on those who falsely implicated his father. When an officer has raised the problem of violent movie influencing this killing, Justice Altamas Kabir, Judge of Supreme Court, who was here in Hyderabad (on 12 $2^{\text {th }}$ February 2012) at a sensitization meeting of Judicial Officers and CWC members on Juvenile Justice and rights of children, responded saying that the censoring of the films should be done strictly and the violence on celluloid should be checked.

Cinema coupled with its repeated telecast on TV channels will certainly have a more imprinting effect on the minds of the young. Like a fresh and empty hard disc, their mind will retain whatever is loaded onto it, a young mind receives and stores anything that attracts and that influences it. Cinema with a colorful bigger image than life-size, associated with sound and music in tune with a theme adds to its impact. When the same program is repeated over TV channels, the memory of the young mind gets consolidated which nobody can erase or delete. If such an effective medium tells about the story of revenge glorifying a negative and destructive character, society has to suffer the consequences. This exactly is the reason that justifies the precensorship of feature films which is more global commerce than art.

Under the Cinematography Act 1952, a mechanism of preview and censorship is created to secure young minds. However, its dynamics like the way the selections are made to the Board of Film Certification, the attitude and background of those members, prevalent corruption because of high stakes involved in making a movie, etc are the factors that run against the objectives of this law. If the Board directed deletion of certain scenes from the movie, that information should be displayed to the audience in the lobbies of cinema theater and even that should be part of the projected cinema so that a spectator could read it and check whether such a scene is deleted or not. Unfortunately, this vital information is printed on the back of the certificate which permits exhibition with cuts, and thus provides scope for remixing of deleted scenes at the theater. This kills the entire purpose of law and leaves young minds to the onslaught of violence and obscenity-filled in the movie. The influence of commercial media and the lobbying of mighty producers and star actors will not allow the members of the board to work independently. Hence cinema creates its quota of criminals in society. 


\title{
3 Results and Discussions
}

\author{
Several Reports by Media
}

Hindustan Times :( New Delhi), reported that, in the age of lost innocence, the term 'criminal children' is not an oxymoron. If numbers are a fair indication, juvenile crime in the Capital and NCR saw a disturbing increase of 8.9\% in 2008 and 7.8\% in 2007, according to police reports. And a kid committing the crime is not only a Capital affair but the trend has an alarming echo across the country. An offense committed by minors was $1.7 \%$ of total crime in the country in 2005. It increased to $1.9 \%$ and 2\% in 2006 and 2007 respectively, according to the National Crime Records Bureau (NCRB) report.

The Time of India (Jan 26, 2005, New Delhi): The crime rate by juveniles has been low despite the higher growth of the population in the country. A National Crime Bureau (NCB) statistic suggests the cases of children delinquencies against total crimes have been almost constant for the last 12 years vis-a-vis population overgrowth. Cases in 1992 were slightly over 11,000 against total recorded crimes in the country at 17,00,000, which was 0.7 percent. From 1993 to 2000 the rate was between 0.6 to 0.5 , which rose in 2001 at 0.9 and in 2002 at 1 percent. The trend in 2003 and 2004 is still not available, though seems similar. BBC NEWS (ON 8 August 2014), Reported on, 'Indian media: Punishing juvenile crime'. The report said that Media in India welcome the government's decision to approve a bill to allow children over 16 to be tried as adults for crimes like rape and murder. But there is also concern that the move might be rushed in because of public outrage at the growing number of grave offenses committed by teenagers.

The Times of India, said, the government bill "a brave new step" that shows the authorities are taking note of the debate in society "on the need to change punishments given to youth old enough to know the nature of violent crimes they're participating in".

Hindustan Times recalls that the gang rape of a student in Delhi in 2012 and the involvement of a juvenile in the attack had "triggered a ferocious debate" on whether existing legislation should be amended. The daily says that, according to statistics, the number of rapes committed by juveniles had more than doubled from 485 in 2002 to 1,149 in 2011 and comments that the step to change the law "will definitely pacify the public". "The Juvenile Justice Act in its present form provides a shield to such [juvenile] criminals, who get a maximum of three years in a reforms home for even the worst barbarity". The paper questioned that, whether we should treat all acts of juvenile delinquency as serious crimes and lock up youngsters in the same jails as adults, given the stifling atmosphere of our criminal justice system,.

The Indian Express Reported, in rushing to amend the law on juvenile offenders above 16, the government seems to be responding to the baying of the mob rather than reason, how a child in need of care and protection turns into a juvenile offender is often a story of how society and its institutions have let him down. In criminalizing him further, it is abdicating all its responsibility. BBC NEWS stated (13 January 2019), Blue Whale: What is the truth behind an online 'suicide challenge'? The "Blue Whale challenge" was reported to be an online "suicide game" aimed at teenagers which set 50 tasks over 50 days. The challenge was alleged to be linked to numerous deaths around the world. But little about the "game" was quite as it seemed. The challenge was alleged to have started in Russia, but reports of it soon spread to other countries: Ukraine, India, and the States. Hundreds of deaths were reported to be linked to the so-called "suicide game". National Herald reported, Blue Whale suicide game now available under different names: UNESCO advisory Curators are getting in touch with vulnerable targets and are giving them tasks to complete; the final task is to commit suicide. The advisory further stated that although the government has asked companies such as Google, Facebook, WhatsApp, Instagram, Microsoft, and Yahoo to immediately take down any links leading to the deadly game, it remains unclear how these companies would make the game inaccessible.

\section{Conclusion}

Moreover, records of Juvenile offenders are to be kept strictly confidential and closed to third parties and not be used in adult proceedings in subsequent cases involving the same offender. These provisions are inserted

Chakraborty, N. (2021). Articulation of media on juvenile delinquency with special reference to India. International Journal of Social Sciences and Humanities, 5(1), 32-44. https://doi.org/10.29332/ijssh.v5n1.850 
to avoid stigma and to enable a juvenile offender to enjoy opportunities offered to other children his age. Nor should an unlawful act committed due to immaturity of Judgment be treated as his antecedents.

The two major findings:

- The juvenile's Right to privacy shall be respected at all stages to avoid harm being caused to her or him by undue publicity or by the process of labelling.

- In principle, no information that may lead to the identification of a juvenile offender shall be published.

The media has, in a way, changed people's outlook towards life. Media is the interface through which millions look at the world outside. Media claims to depict the 'today', but not all types of media show only the truth. With the intent of stressing their point or grabbing greater attention from the masses, the media hypes or exaggerates things to a certain degree. Not everyone can filter that element. Most believe everything to be real, especially kids and teenagers.

A child is born innocent and if nourished with tender care and attention, he or she will blossom with faculties physical, mental, moral, and spiritual, into a person of stature and excellence. On the other hand noxious surroundings, neglect of basic needs, bad company, and other abuses and temptations would spoil the child and likely turn him or her delinquent. The children being an important asset, every effort should be made to provide them equal development opportunities, so that they become robust citizens physically fit, mentally alert and morally healthy endowed with the skills and motivation s needed by society. "The children of today will make the India of tomorrow. The way we bring them up will determine the future of the country," said Pandit Jawahar Lal Nehru.

Rabindranath Tagore said, "Children are living beings - more living than grown-up people who have built shells of habit around themselves. Therefore it is necessary for their mental health and development that they should not have mere schools for their lessons, but a world whose guiding spirit is personal love." We have to remember always, that, "Every child comes with the message that God is not yet discouraged of man."

\section{Acknowledgments}

I am grateful to two anonymous reviewers for their valuable comments on the earlier version of this paper. 


\section{References}

Attar, A. D. (1964). Juvenile delinquency: A comparative study. Popular Prakashan.

Bhattacharya, B. K., Das, P., \& Sen, A. B. (1962). Changes Observed in Trypanosoma Evansi From Antrycide and Suramin Treated Rats. Archives internationales de pharmacodynamie et de therapie, 135, 356-363.

Chabrol, H., Van Leeuwen, N., Rodgers, R., \& Séjourné, N. (2009). Contributions of psychopathic, narcissistic, Machiavellian, and sadistic personality traits to juvenile delinquency. Personality and individual differences, 47(7), 734-739. https://doi.org/10.1016/j.paid.2009.06.020

Chandra, S. (1967). Sociology of deviation in India. Allied Publishers.

Chopra, G. (2015). Child rights in India. New Delh: Springer, 45-76.

Desai, A. N. (1979). Juvenile Delinquency in India: A Psychological Analysis. HA Desai.

Dietrich, K. N., Douglas, R. M., Succop, P. A., Berger, O. G., \& Bornschein, R. L. (2001). Early exposure to lead and juvenile delinquency. Neurotoxicology and teratology, 23(6), 511-518. https://doi.org/10.1016/S08920362(01)00184-2

Huston, A. C. (1992). Big world, small screen: The role of television in American society. U of Nebraska Press.

Ivory, M. Y., Sinha, R. R., \& Hearst, M. A. (2001, March). Empirically validated web page design metrics. In Proceedings of the SIGCHI conference on Human factors in computing systems (pp. 53-60).

Juvenile Delinquency Guidelines: Improving Court Practice in Juvenile Delinquency Cases Sixteen Key Principles. (2005). Juvenile and Family Court Journal, 56(3), 41-49. https://doi.org/10.1111/j.17556988.2005.tb00109.x

Kumari, V. (2011). Juvenile Justice System in India: From Welfare to Rights (Second ed.). Oxford University Press.

Moffitt, T. E., Caspi, A., \& Rutter, M. (2006). Measured gene-environment interactions in psychopathology: Concepts, research strategies, and implications for research, intervention, and public understanding of genetics. Perspectives on Psychological science, 1(1), 5-27.

Mulvey, E. P., Arthur, M. W., \& Reppucci, N. D. (1993). The prevention and treatment of juvenile delinquency: A review of the research. Clinical Psychology Review, 13(2), 133-167. https://doi.org/10.1016/02727358(93)90038-N

Pearl, D., Bouthilet, L., \& Lazar, J. (1982). Television and behavior: Ten years of scientific progress and implications for the eighties (DHHS Publication Nos. ADM 82-1195 \& ADM 82-1196). Rockville, MD: US Dept. of Health and Human Services. Public Health Service, Alcohol, Drug Abuse, and Mental Health Administration, National Institute of Mental Health.

Report of the Media Violence Commission. (2012). Aggressive Behavior, 38(5), 335-341. https://doi.org/10.1002/ab.21443

Ryan, J. P., Marshall, J. M., Herz, D., \& Hernandez, P. M. (2008). Juvenile delinquency in child welfare: Investigating group home effects. Children and Youth Services Review, 30(9), 1088-1099. https://doi.org/10.1016/j.childyouth.2008.02.004

Sandhu, J. S., Bhagat, S. A. S., Thakur, P. D., Gupta, M. G., Singh, J., Kalra, R. L., ... \& Kohli, H. S. (1977). Statistical Abstract of Punjab, 1977. Economic Adviser to Government, Chandigarh.

Sheth, H. (1961). Juvenile delinquency in an Indian setting. Popular Book Depot.

Verma, S. C. (1969). The Young Delinquents: A Sociological Enquiry. Lucknow: Pustak Kendra.

Chakraborty, N. (2021). Articulation of media on juvenile delinquency with special reference to India. International Journal of Social Sciences and Humanities, 5(1), 32-44. https://doi.org/10.29332/ijssh.v5n1.850 


\section{Biography of Author}

\begin{tabular}{|l|l|}
\hline & Assistant Professor, Head, Department of Journalism and Mass Communication, at \\
Mrinalini Datta Mahavidyapith, Birati, Kolkata (under West Bengal State \\
University). She has completed her M.A in Journalism and Mass Communication, \\
from the University of Calcutta, in the year 2002. And also completed her M.A in \\
Human Rights, from Indian Institute of Human Rights, New Delhi, in the year \\
2004.She has worked as trainee Journalist in Aajkal Patrika. Worked as Guest \\
Lecturer in IGNOU. She has 11 years teaching experience. \\
Email: chakrabortynandini009@gmail.com
\end{tabular}

